\title{
Indicators of development of civil society in Uzbekistan
}

\begin{abstract}
The article deals with the main factors of civil society development in Uzbekistan. It is noted that civil society is gradually and consistently built in Uzbekistan, enriched by new trends and components. In this regard, the article has developed and analyzed indicators for assessing the development of democracy and civil society. The recent socio-political reforms implemented under the leadership of President Sh. Mirziyoyev have been considered as well. The scientific article mainly uses general theoretical and empirical methods - system, structural and institutional, widely used in social and political sciences. In addition, the scientific-theoretical and factual base of civil society institutions in Uzbekistan has been collected and analyzed.
\end{abstract}

Keywords: civil society, indicators, non-governmental non-profit organizations, financing of NGOs, mahalla, social capital, democracy, international relations, socioeconomic situation, republic of Uzbekistan, legislative acts, oliy majlis, dehkans
Special Issue - 2018

\author{
Sanjar Sh. Saidov \\ Political scientist, Uzbekistan
}

Correspondence: Sanjar Sh. Saidov, Political scientist,

Uzbekistan, Email s.saidov.uz@gmail.com

Received: July 31, 2018 | Published: December 31, 2018

\section{Introduction}

The fact that no country or region is currently able to exist and develop in isolation from the rest of the world has already become a universally recognized truth. One of the first evidences of this trend is the growing desire to assimilate and introduce more and more so-called universal values in the form of democratic governance principles, the rule of law, respect for human rights and the construction of civil society. Today, one of the most important elements of the positive image of states in the world arena is not only their active participation in international relations, but also their ability to fulfill the following tasks in domestic politics: the introduction of a system of democratic governance, the achievement of domestic economic stability, the establishment of the rule of law, respect for human rights, the formation and support of civil society institutions and others. At the same time, the formation and development of a strong civil society remains the main task for each country. Civil society is an integral part of the development of social relations and the most important guarantee of democracy, the rule of law and individual freedom in the state. As is known, today in the world science the tendencies of scientific study of the concept of civil society are strengthened on the basis of theoretical and practical research. Thus, the measurement of the level of development of civil society is one of the important areas of empirical research. In modern political and legal sciences, a number of indicators are being developed that are effectively used in research and determine the level of development of civil society and democracy in each country. It should be noted that civil society is gradually and consistently being built in Uzbekistan; the President of the Republic of Uzbekistan adopted a decree "On measures to radically increase the role of civil society institutions in the process of democratic renewal of the country" in May 2018. In connection with the relevance of the issue, it is advisable to analyze some indicators of the development of civil society.

Formation of effective legislative bases for free and independent non-governmental non-profit organizations and other institutions of civil society

On a constitutional basis, it is enshrined that: the state ensures observance of the rights and legitimate interests of public associations creates equal legal opportunities for them to participate in public life. ${ }^{1}$ And also, it should be noted that during the years of independence a broad legal space for active and, most importantly, for the practical activities of various political and social movements and nongovernmental organizations was created. ${ }^{2}$ More than 200 legislative acts were adopted in the country aimed at enhancing the role and participation of civil society institutions in addressing pressing social and economic problems of citizens. Laws of the Republic of Uzbekistan "On public associations", "On non-governmental nonprofit organizations", "On social partnership" and other legal acts have formed a unified system to support NGOs and the development of social partnership in society. At the same time, it should be specially emphasized that in Uzbekistan non-governmental nonprofit organizations are growing quantitatively and qualitatively. Currently, there are more than 9,000 NGOs in the country, branches and representative offices of 29 international and foreign nongovernmental organizations. The following tables provide a statistical analysis of trends in the development of NGOs in Uzbekistan, their classification and role in various social spheres of life (Figure 1). ${ }^{3}$ The main reasons and growth factors of NGOs in the country are: the growth of the country's population; increase socio-economic and socio-political needs of citizens of Uzbekistan.

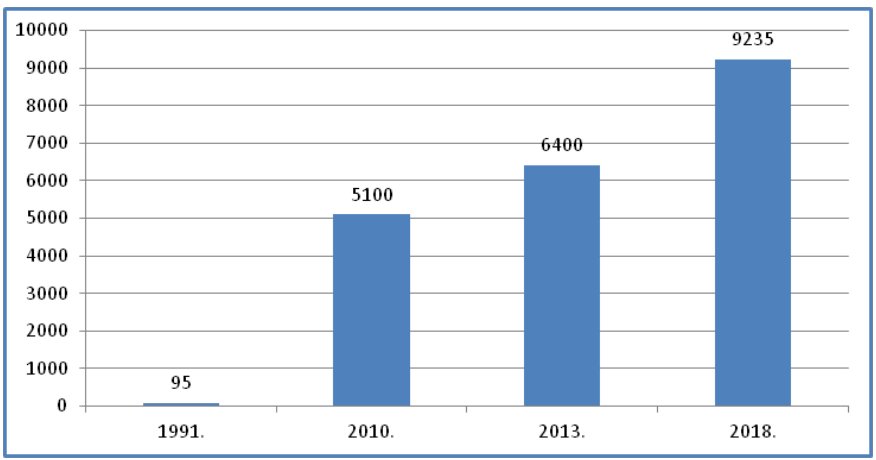

Figure I Dynamics of quantitative growth of non-governmental non-profit organizations in Uzbekistan. ${ }^{3}$ 


\section{The formation of economic and organizational guarantees for the development of civil society institutions in the country.}

In this direction, the joint decision of the Kengash of the Legislative Chamber of the Oliy Majlis (Parliament of Uzbekistan - author) of the Republic of Uzbekistan and the Senate of the Oliy Majlis of the Republic of Uzbekistan "On Measures to Strengthen Support for Non-Governmental Non-Profit Organizations and Other Civil Society Institutions", adopted in 2008, is of great importance. In this context, the establishment of the Public Fund for Supporting NGOs and Other Civil Society Institutions under the Parliament and the creation of a parliamentary commission for the management of the Fund's resources have become an important social event (Figure 2).

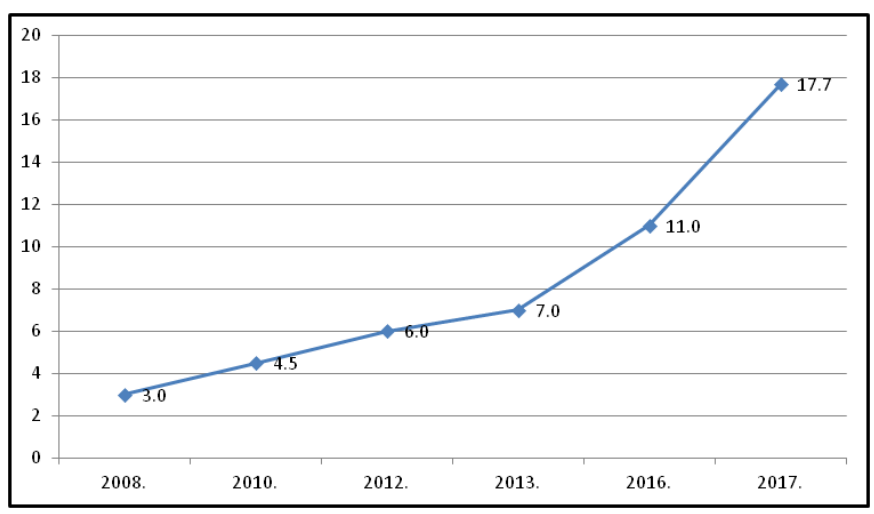

Figure 2 Dynamics of state financing of NGOs in Uzbekistan (in billions of sums).

A multi-party system has emerged in Uzbekistan as an integral part of the rule of law and civil society.

Legal foundations of the activity of political parties are formed; their place and role in state and public construction are strengthened. It is also important to raise the effectiveness of political parties in the activities of representative bodies of state power. Another criterion for the multiparty system is the activity of party factions in the parliament, their participation in drafting bills, control and analytical work of the Oliy Majlis. Formation of a new social institution in the social sector - The Environmental Movement of Uzbekistan also played an important role in the development of civil society (Figure 3).

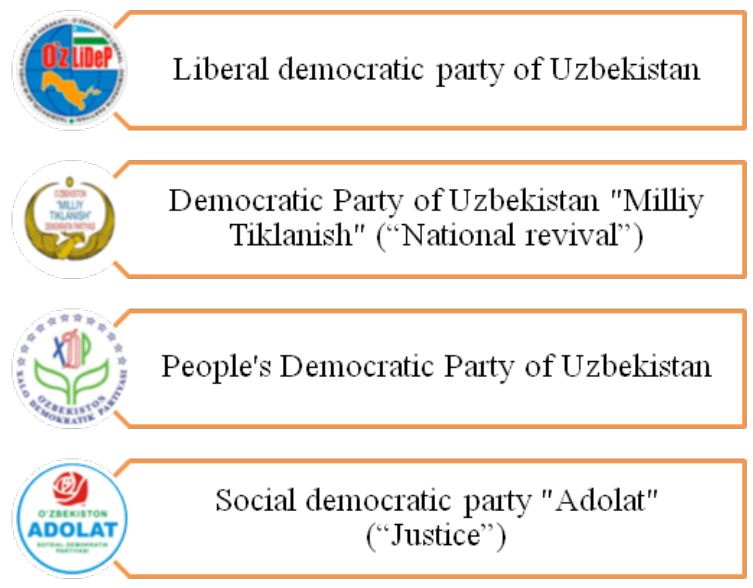

Figure 3 Political parties of Uzbekistan.

\section{The openness and effectiveness of the media}

In the process of development of civil society in Uzbekistan, the mass media have become an important element in meeting the public's need for information and, at the same time, increasing their consciousness, worldview and political culture and strengthening their civic position. From the first days of independence, step-bystep works on reforming the information sphere, ensuring freedom of speech and information, supporting and developing the mass media are being implemented in the country. Today, more than ten laws have been adopted in this area, and the necessary legal and institutional conditions for the professional work of journalists have been created. In particular, the Laws "On Informatization", "On Mass Media", "On Telecommunications", "On Advertising", "On Copyright and Related Rights", "On the Protection of Journalistic Activity", "On the Principles and Guarantees of Freedom of Information" is a powerful foundation in the activities of the media in Uzbekistan. In order to support non-state media, strengthen their material and technical base and human resources, a number of non-governmental organizations, the National Association of Electronic Media (NAEMM), was established, which now includes more than 100 electronic media, the Public Fund for Support and Development of Independent Print Media and News Agencies of Uzbekistan. Today there are more than 1500 mass media in the republic. They differ in the form of ownership, direction, method of transferring the information. ${ }^{4}$

\section{At present, the principles of direct dialogue with the public}

The functioning of a qualitatively new and effective system of dealing with appeals from individuals and legal entities aimed at fully protecting their rights, freedoms and legitimate interests of citizens can be an important indicator of the evaluation of the formation of civil society. In this regard, the Decree of the President of the Republic of Uzbekistan of December 28, 2016 "On measures to radically improve the system of work with appeals of individuals and legal entities" is to be noted. According to these legal grounds, the "Virtual Reception" was established by the President of the Republic of Uzbekistan and the "People's Reception" throughout the country. The main goal of the people's reception centers is practical approval of the principle "not the people should serve state bodies, but state bodies should serve the people" in the activity of state bodies at all levels of the principle, as well as the introduction of a qualitatively new system of work with the appeals of individuals and legal entities. ${ }^{5}$ In addition, there are "virtual reception rooms" of state bodies at all levels. Each appeal received at the reception offices is studied, analyzed and the control of a positive decision of this issue is monitored.

\section{Monitoring of the processes of deepening democratic reforms}

Identifying factors that affect the social well-being of the population, organization and conducting sociological research on civil society. A common and important indicator of civil society is that people give their assessment of what is happening in the country, and feel they contribution to a growing social group. The current legislative framework is the legal basis for monitoring the processes of deepening democratic reforms. In this context, for example, it is possible to assess the participation of civil society institutions in the implementation of state, territorial and other programs in the field of occupational safety, assist state and other bodies involved in labor protection, and participate in other activities in accordance with the 
law, ${ }^{6}$ as well as to study the participation of NGOs, self-governing bodies of citizens, the media and other institutions of civil society in the provision of social services in society. ${ }^{7}$

\section{Further improvement of the self-government system}

During the years of independence, the legal basis for the activity of citizens' self-government bodies in the person of the mahalla ${ }^{8}$ institution was strengthened and developed. This institution is formed as an integral part of the political, economic and spiritual life of the country, and all the necessary conditions for the development of the mahalla have been created. The upgrading of the status of the mahalla has been enshrined in the Law "On Citizens' Self-Government Bodies", which provides ample opportunities for increasing the activity of the mahalla residents in the course of democratic transformations in the society. The mahalla as a proven historical form of self-government is fully consistent with the nature and needs of the people of Uzbekistan, a reliable factor in preserving and strengthening the country's peace and harmony, and social stability. This is facilitated by the process of expanding the powers of mahalla gatherings and aksakals (a village elder, a headman in mahalla.) At present, the number of citizens' gatherings and self-government bodies - mahalla committees has exceeded 10 thousand throughout the country, since the mahalla committees are seen as the backbone of civil society in Uzbekistan. The Decree "On Measures for Further Improvement of the Mahalla Institute", adopted by the President of the Republic of Uzbekistan on February 3, 2017, is of particular importance for the further strengthening of self-governing bodies of citizens, the improvement of the mahalla institute into targeted social protection of the population (Figure 4).

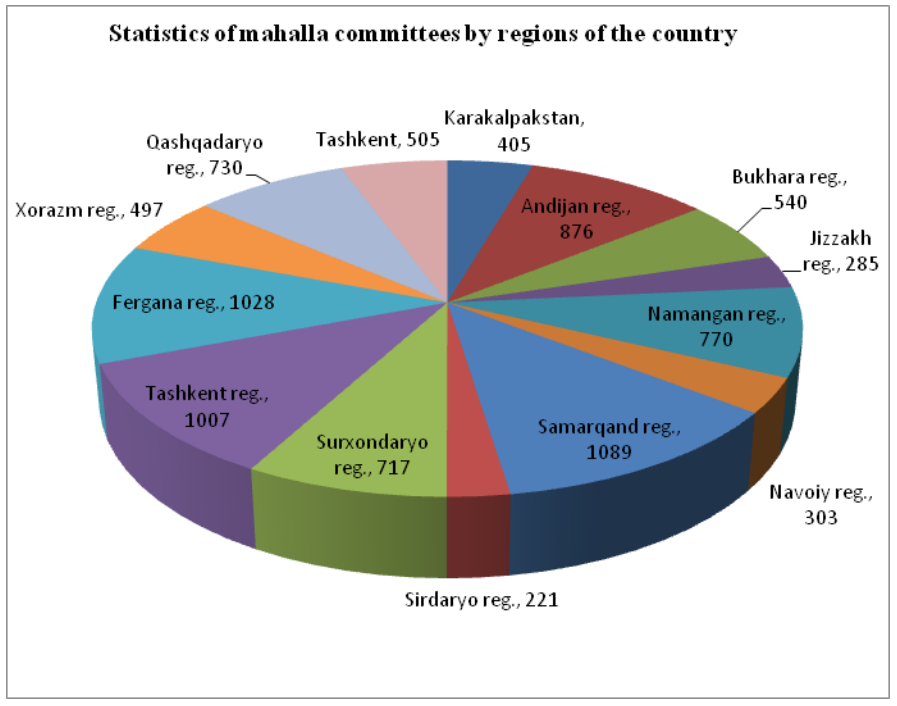

Figure $\mathbf{4}$ Statistics of committees by regions of country.

\section{Development of socially significant projects.}

Development of social significant projects of state and public organizations in the implementation of state youth policy. The promotion of spiritual, intellectual, physical and moral development of youth, providing young people with affordable and quality education, creating conditions for employment and employment youth. It should be noted that, in accordance with the current legislation, the media and citizens' self-government bodies cooperate with other bodies and institutions, NGOs and other institutions of civil society in the implementation of state youth policy. ${ }^{9}$

\section{Degree of openness of civil society}

It should be noted that another criterion for assessing the degree of openness of civil society is the contribution of the private sector to the economy and the development of entrepreneurial activities in the country. Over the past three years, Uzbekistan has risen from 154th place to $42 \mathrm{nd}$ in the international rating of "small business lending," and has increased its rating by 63 points in 2017. As a result of comprehensive measures aimed at removing barriers to further improving the business environment in the country, protecting small businesses and private entrepreneurship, and their full support, it has enabled rapid development and the creation of new small enterprises. As a result, as of January 1, 2017, the number of operating small businesses was 218.170 (excluding dehkans (term for an individual or family farm in Central Asia) and farms..$^{10}$ With the development of entrepreneurship and business, the "middle class" is formed in the country as an important indicator of civil society. The further development and expansion of the "middle class" is of great importance not only for social relations, but also for economic and political stability in the country. ${ }^{11}$

\section{Civil society}

Civil society is measured not only on a legal, economic, social or political basis, but also through an important and final indicator of civil society - the development of social capital. As social thinking, legal culture, social activity and civic position of people grow, civil society becomes a national value in the country. This, in turn, will lead to the development of social capital by expanding the network of social institutions, the formation of social norms and the strengthening of trust. At the same time, as a result of scientific research and analysis, it can be noted that today there are some shortcomings and problems in the process of forming a strong civil society and in the activities of non-governmental non-profit organizations in Uzbekistan. The issues of financing non-governmental non-profit organizations and other civil society institutions are still relevant. The funds allocated by the Public Fund in the Parliament are still in the disproportionate quantitative and qualitative growth of NGOs in the country. There are tendencies of excessive centralization and monopolization of the revenues of all forms of financial resources and assistance for NGOs in Uzbekistan (articles 2 - part 1, 3 - part 1, 4 of the joint Resolution), strengthening control over the work of DNAs by excessive interference with the definition of priority activities, programs and projects for NGOs raising the issue of financing NGOs by the Public Fund, depending on "the choice of feasible and acceptable projects / programs". Considering the problem of financing civil society institutions in the country, unfortunately, for the time being it will be necessary to exclude membership fees of public associations or charitable donations of citizens and organizations from the list of material assistance, since low income levels, high unemployment and lack of an effective fundraising strategy for domestic NGOs affect negatively on this issue. The following table shows that the number one problem of NGOs in Uzbekistan is the lack of funding. The following positions are occupied by the problems of staff shortages and the absence of inter-sectoral social ties (Figure 5).

Over the past two years, practical reforms have been carried out to further improve the activities of NGOs. For example, in 2017 
separate decrees and decrees were adopted to improve the activities of such non-governmental non-profit organizations as the Nuroniy Foundation, the Youth Union, the Council of Farmers, Dehkan Farms and Household Landowners, the Chamber of Commerce and Industry, the Republican Council for Coordinating the Activities of Self-Government Bodies citizens, their support. However, despite such measures, the participation of public organizations in systematic study of the population's problems, their resolution, especially in supporting women who find themselves in a difficult social situation, prevent crime and crime among young people and women, and their employment is not properly felt. These organizations mainly deal with formal events. ${ }^{4}$ Throughout the entire period of its existence, under the pressure and internal policy of self-censorship, the existing institutions of civil society in Uzbekistan (NGOs, political parties, the media, etc.) have not been able to turn into strong analytical, brain and ideological centers of civil society that would be able to offer alternatives to official options development model for the country. Instead, they were mainly engaged in organizing and conducting activities among the population with the goal of promoting and popularizing government programs, action plans and regulations. Also, despite the creation of a sufficient legislative base, social partnership could not become an effective mechanism for interaction between state bodies and nongovernmental non-profit organizations aimed at solving a wide range of social problems of citizens, real progress in their initiatives and modern ideas, especially for young people.

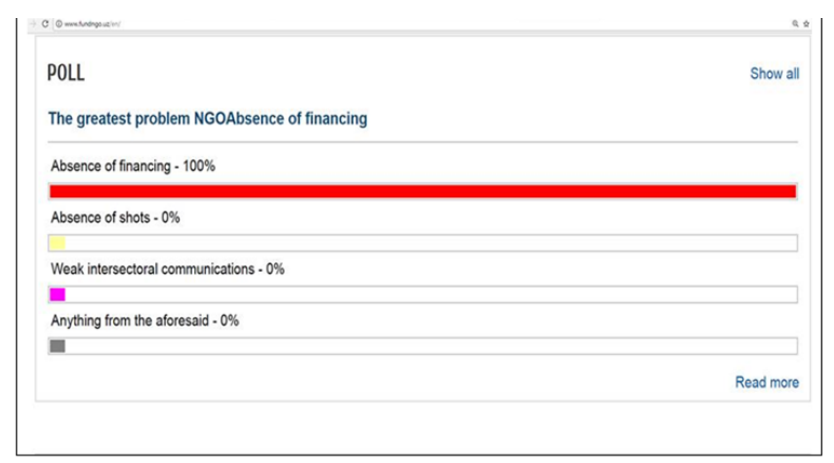

Figure 5 Public opinion poll conducted on the official website of the Public Foundation under the Parliament. ${ }^{12}$

\section{Conclusion}

Based on the analysis, one can note that in Uzbekistan there is an increasing tendency to delegate some of the traditionally public functions (mostly socially oriented functions or functions with the nature of public control) to individual institutions of civil society, while retaining leadership functions for government departments. This, in fact, is the beginning of positive changes in society. Shavkat Mirziyoyev's ${ }^{4}$ recent initiative to create the Consultative Council for the Development of Civil Society under the President of the Republic of Uzbekistan is one of the main tendencies of strengthening the role of civil society in the country. Thus, there is a limited, very peculiar strengthening of interaction between civil society and the state. Nevertheless, it is important to highlight some recommendations for strengthening the institution of civil society:

a. Civil society as an equal and independent institution in Uzbekistan is still at the stage of formation. This issue deserves more careful study, as well as support from a more active and not indifferent part of society and relevant structures.

b. Uzbekistan should refrain from various ways of putting pressure on independent and critical Internet resources (including the media) under various pretexts (for example, under the pretext of combating extremism and radicalism). Otherwise, this can nullify the only remaining space where it is possible to exist and publish a free, independent opinion with great difficulty.

c. Based on the difficulties in the socio-economic situation of the country, Uzbekistan should gradually choose a more open position vis-à-vis international donors and their social programs in the country.

d. The NGO's focus on state bodies, the paternalistic nature of public administration, low critical thinking, low level of motivation for direct dialogue with the people - all this currently hinders the development of civil society in Uzbekistan. Only the formation of a system of permanent communication between various public organizations, trade unions, business structures and the media will allow NGOs to unite different social strata and classes around the national idea and to attract additional resources to support their activities.

\section{Acknowledgements}

None.

\section{Conflict of interest}

Authors declare that there is no conflict of interest.

\section{References}

1. Constitution of the Republic of Uzbekistan. 2017; Chapter XIII:article 58.

2. Karimov IA. On the path of security and stable development. Uzbekistan; 1998.

3. National association of non-governmental non-profit organizations of Uzbekistan.

4. The message of the President of the Republic of Uzbekistan Shavkat Mirziyoyev to the Oliy Majlis.

5. Decree of the President of the Republic of Uzbekistan. On Measures for the Basic Improvement of the System of Work with Appeals from Individuals and Legal Entities; 2016.

6. Law of the Republic of Uzbekistan. On labor protection; 2016.

7. Law of the Republic of Uzbekistan. On social services for the elderly, disabled people and other socially vulnerable categories of the population; 2016.

8. Mahalla (mahalla committee) is an institution exercising local selfgovernment.

9. Law of the Republic of Uzbekistan. On State Youth Policy; 2016.

10. Development of small business and private entrepreneurship. Governmental portal of the Republic of Uzbekistan.

11. Saidov S. The question of the "middle class" in Uzbekistan. Journal of Economy and Business. 2015;2.

12. Poll. The greatest problem NGO-Absence of financing. 